\title{
Sustainable Urbanization in the Arabian Gulf Region: Problems and Challenges
}

\section{Ramadan $E^{*}$}

Department of Geography, College of Arts and Social Sciences, Sultan Qaboos University, Muscat, Oman

\begin{abstract}
The Arab Gulf States has been undergoing transitions, from traditional economies and societies to states of modern development over the past 40 years. The Gulf Coorpation council States(GCC) include Saudi Arabia, Kuwait, Qatar, Bahrain, Oman and United Arab Emirates. They are all located inarid region of the Arabian peninsula. They are small in area and population and major oil producers; their oil revenues have entirely dominated their economies in every facet of their national life sincelate sixties and early seventies. These States have experienced a tremendous total and urban population growth; the total population grew from 860,000 in 1965 to 2,100,000 in 1975 to $3,60,00,000$ in 2008 . About $90 \%$ of this total population are urban dwellers. The high growth rates has been the result of very high levels of immigration as well as natural increases due to oil revenues being invested in health, welfare, and educational facilities which have reduced mortality rates. The objective of this article is to shed light on the serious problems that face urbanization in these states and the challenges of building sustainable urban strategy in the region.
\end{abstract}

Keywords: Urbanization; Environment; Arabian Gulf states; Migration

\section{Introduction}

The Gulf Cooperation Council (GCC), comprised of six States of Saudi Arabia, Kuwait, Qatar, Bahrain, Oman and United Arab Emirates (Figure 1) is home to a population of over 40 million residents, of whom nearly 67 percent reside in Saudi Arabia. With the exception of Qatar, total population growth has been relatively slow and declining. The GCC is one of the most urbanized areas in the world, with over 70 per cent of the population living in urban areas and with Kuwait and Qatar almost 100 per cent urbanized. Urban expansion in the region has been fuelled by both internal migration and the influx of expatriate workers attracted by the region's economic prosperity and employment opportunities.

Historically, life in these states was nomadic,the most prevailing activities were pearling and fishing on the coasts, where most of the oldest towns first developed and connected with trade ties with with India and the rest of the world. The discovery of oil in the 1960s has increased wealth and spurred significant development and economic expansion. The GCC countries now have among the highest economic GDP per capita in the world. This situation had led to a population boom and the exponential economic development that transformed the mud-walled towns intocommercial capitals integrated into the global economy [1-6].

The urban populations in the Arabian Gulf states have continued to grow more rapidly than the total populations, implying continued urbanization. Therefore, it will be important to manage this urban growth to prevent unplanned and chaotic informal development (Table 1).

This change toward high urbanization in these States have made the cities of the region occupy a central stage in global development. They no longer function as mere spaces for settlement, production and services. They now profoundly shape and influence social and political relations at every level; determining advances and setbacks in modes of production; and providing new content to norms, culture and aesthetics. Cities of the region have become a major locus of power and politics consequently influencing vision achievement and dictating policy outcomes. They also have a serious impact on environmental and sustainability processes. Urbanization trends in the region is thus providing the setting, the underlying base, and also the momentum for various changes. The shift towards a dominantly urban context is not simply a demographic phenomenon characterized by an anticipated population movement and changes from other parts of the world and to region. Rather, it is a transformative process which represent drive that push manyother aspects of global development. It is also a dynamic process with various impacts.

\section{Migration to the Region}

The unprecedented scale of development projects in the GCC countries following the october 1973 "oil boom" led to an extremely rapid increase in the demand for foreign labor, as the GCC national workforces at that time were too small and without the required skills to execute these projects. Hence, while the short-term solution to the labor shortage was recruiting migrant labor, the longer term solution was the implementation policy of huge investment in education and vocational training in order to supply the necessary workforce from local sources. Hence the number of foreign laborers in the GCC countries rapidly increased, amounting to almost 4.4 million in 1985, a more than three-fold increase within a single decade. The total number of the foreign population was much higher, since many of the foreign workers, particularly the Arabs, were accompanied by their family members. In 2010 the majority of GCC populations consisted of expatriates, which in some countries, such as Kuwait, Qatar and UAE, largely exceeded the number of national inhabitants (Figure 2). For

*Corresponding author: Ramadan E, Department of Geography, College of Arts and Social Sciences, Sultan Qaboos University, Muscat, Oman, Tel: 96824142954; E-mail: alnazir@squ.edu.om

Received June 23, 2015; Accepted July 20, 2015; Published July 24, 2015

Citation: Ramadan E (2015) Sustainable Urbanization in the Arabian Gulf Region: Problems and Challenges. Arts Social Sci J 6: 109. doi:10.4172/21516200.1000109

Copyright: (c) 2015 Ramadan E. This is an open-access article distributed under the terms of the Creative Commons Attribution License, which permits unrestricted use, distribution, and reproduction in any medium, provided the original author and source are credited. 
Citation: Ramadan E (2015) Sustainable Urbanization in the Arabian Gulf Region: Problems and Challenges. Arts Social Sci J 6: 109. doi:10.4172/21516200.1000109

Page 2 of 4

\begin{tabular}{|c|c|c|c|c|c|}
\hline \multirow[t]{2}{*}{ Country } & \multicolumn{3}{|c|}{ Total Population } & \multicolumn{2}{|c|}{ Average Rate of Population Growth } \\
\hline & 1970 & 2010 & 2050 & $1970-2010$ & 2010-2050 \\
\hline World & 3.685 .777 & 6.908 .688 & 9.194 .984 & $1.58 \%$ & $0.72 \%$ \\
\hline Dev. Country & 2.678 .300 & 5.671 .460 & 7.874 .742 & $1.89 \%$ & $0.82 \%$ \\
\hline Arab Reg. & 127.865 & 359.273 & 598.174 & $2.62 \%$ & $1.28 \%$ \\
\hline Bahrain & 220 & 807 & 1.277 & $3.30 \%$ & $1015 \%$ \\
\hline Kuwait & 744 & 3.051 & 5.240 & $3.59 \%$ & $1.36 \%$ \\
\hline Oman & 747 & 2.905 & 4.878 & $3.45 \%$ & $1.30 \%$ \\
\hline Qatar & 111 & 1.508 & 2.316 & $6.74 \%$ & $1.08 \%$ \\
\hline KSA & 5.745 & 26.246 & 43.658 & $3.87 \%$ & $1.28 \%$ \\
\hline UAE & 225 & 4.707 & 8.253 & $7.90 \%$ & $1.41 \%$ \\
\hline Total GCC & 7.792 & 39.224 & 65.622 & $4.12 \%$ & $1.29 \%$ \\
\hline
\end{tabular}

Source: United Nations (2009a), GIC estimates based on UN data

Table 1: GCC Population Dynamics, Size ('000) and Growth Rate.

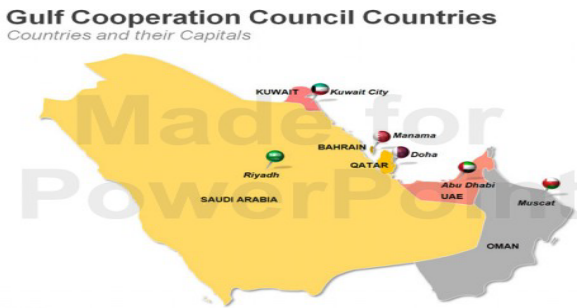

Figure 1: GCC Map.

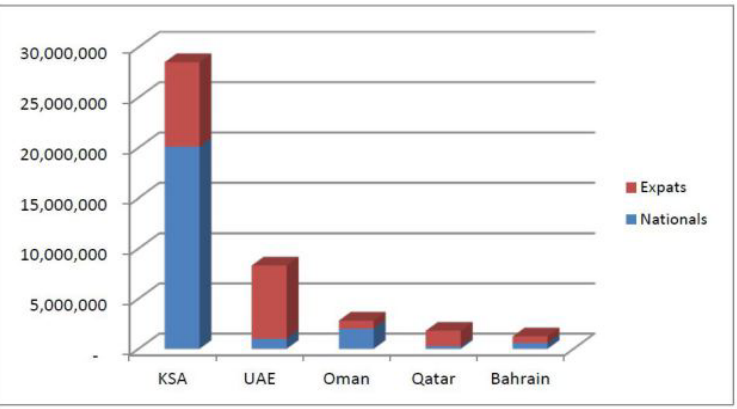

Figure 2: Number of migrant labor in the GCC countries 2010.

decades, the growing non-national component of the population has lived side-by-side with citizens, thus becoming a potential value-laden frame of reference not only affecting labor market efficiency, but also posing new socio-cultural threats. Nationalistic feelings were boosted within the region at the same time as the benefits of being a national in terms of oil revenue became apparent. Therefore, citizenship became not just an identity, but also an entitlement to a comfortable life In this sense, citizenship is perceived as an array of extensive social rights such as free education, free health care, free housing and employment in the public administration. Given the above mentioned context demographic imbalances, high rates of unemployment and pressure from international organizations represent serious economic, social and security problems for the GCC governments [7-9].

\section{The Challenges of Urban Mobility and Public Transportation}

The high income of the Gulf States has facilitated heavy investment

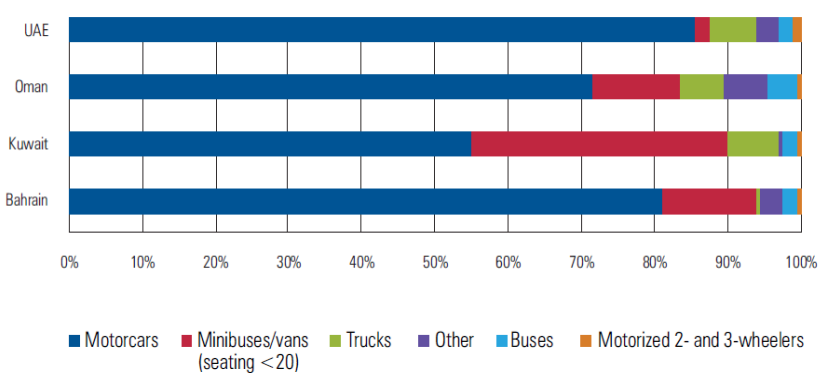

Figure 3: Percentage of registered motor vehicles by category 2007.

in extensive road networks, with high-capacity highways and arterials encircling neighbourhoods and cities. In Oman, massive investment in the road system has created a strong network of roads reaching even remote areas. The country paved and repaired nearly $6,000 \mathrm{~km}$ of roads from 2007 to 2009.152 in Saudi Arabia, Jeddah's network comprises $564 \mathrm{~km}$ of roads, including $100 \mathrm{~km}$ of freeways that by the city's own admission are over-scaled and inefficient consumers of urban land. Concurrent with rising GDP per capita and road construction projects, the Gulf has motor vehicle ownership rates roughly equivalent to those of other high-income countries. From 2004 to 2009 the number of registered vehicles grew by 150 per cent in Bahrain 153, by 149 per cent in Abu Dhabi from 2006 to 2008. 154 and by 143 per cent in Qatar from 2002 to 2007. 155 Riyadh, where, on average, households have 1.7 cars, saw the number of daily vehicular trips increase from 1 million in 2006 and 6 million in 2007 (Figure 3).

Unique among Arab countries, the GCC has the resources to implement ambitious urban transport plans as part of broader development vision. The Gulf governments have developed transportation master plans to reduce congestion and improve public transit, the safety of pedestrian networks and the general quality of urban life. Following the 2008 financial crisis, some development and transit projects have been put on hold or cancelled. Given the long-term value of public transport networks, most of these projects will ultimately move forward. The most ambitious urban public transportation undertakings are in Abu Dhabi, Dubai and Jeddah. Given their small size, Bahrain, Kuwait, Oman and Qatar are focusing on regional rail, bridge and air linkages with other cities in the region; these initiatives are explored in Section 4.8 emerging issues [10-13].

Despite their high rate of motorization, roads in the GCC countries are relatively safe when compared with other Arab countries, although with the exception of Bahrain, less so than in the advanced economies. 
Saudi Arabia and the UAE have the worst road safety record, with an average of 200 accidents per day in Jeddah in 2007, 173 and the UAE has the ninth-highest rate of fatalities in the world. 174 Traffic-related deaths in Oman have consistently risen since 2000 and may soon overtake the rates in Qatar and Saudi Arabia if measures are not taken to improve road safety. Traffic fatalities are also on the rise in Bahrain.

\section{Housing Challenges}

Housing affordability and availability varies across the Gulf and has been driven by high rates of population growth in the 1980s and 1990s. With the exception of Qatar, whose population grew from 7 to 11 per cent annually in the 2000s, population growth has stabilized and is expected to increase by only 1 to 2 per cent annually for the next two decades, with Qatar expected to reach this rate by 2030. Nevertheless, the acute specific age structure of the population is expected to continue to drive the demand for housing. In GCC countries, 52 to 64 percent of the national population is under 25 years of age. 98 In Riyadh, 34 percent of citizens are under 15 and 50 percent are under age 20. The annual rate of household formation was 3,000 a year in with migrant labourers comprising 88,70 and 69 percent of the total population in Qatar, the UAE and Kuwait, their housing conditions and rights require special attention. Although their housing conditions are poor in comparison to the standard of living in the GCC, they are not unlike those of migrants worldwide who try to maximize their remittances. Governments have been reluctant to assume responsibility for privately-sponsored workers, but lately, have begun to consider regulatory reform that would increase oversight of labour importation and a commitment to international labour standards. These reforms are a positive first step to addressing a complex issue. While little information is available on specific migrant labour living conditions, they tend to live in housing built by their employers, low-cost units in the old city or on the premises where they are employed [14-16].

\section{Water Resources Shortage}

With its arid climate and rapidly growing population, the Gulf is one of the most water-scarce regions in the world. Five GCC countries are among the ten countries in the world with the lowest per capita renewable water supply. The region's limited water resources includeshallow aquifers that are replenished by the winter rains andlarger supplies of non-renewable fossil water in deep aquifers formed millions of years ago. Since 1960, population in the GCC has grown sevenfold while water consumption per capita rose by 336 percent in Kuwait from 1992 to 2010 by 125 percent in the UAE from 2006 to 2008 by 120 percent in Muscat from 2005 to 2009 and by 120 percent in Bahrain from 2000 to 2008 . To meet demand, the GCC countries have overexploited existing resources and have begun to invest heavily in desalination facilities. Government investments in water and sanitation infrastructure have achieved near universal access to these basic services throughout the region, with the exception of Oman. While water distribution networks are extensive in cities, many urban and most rural households continue to rely on wells and tankers. As a result of government subsidies, per capita consumption of water in the GCC is among the highest levels in the world. In comparison with consumption levels of 150 to 250 litres per day in the advanced economies, Qataris consume 400 litres and Saudis 250 litres (Figure 4).

\section{Energy Consumption and Air Quality}

Due to the region's extreme temperatures and need for desalinated water, energy demand in the GCC is exceptionally high. Although electricity costs on average USD 0.12 per kWh to produce in the Gulf,

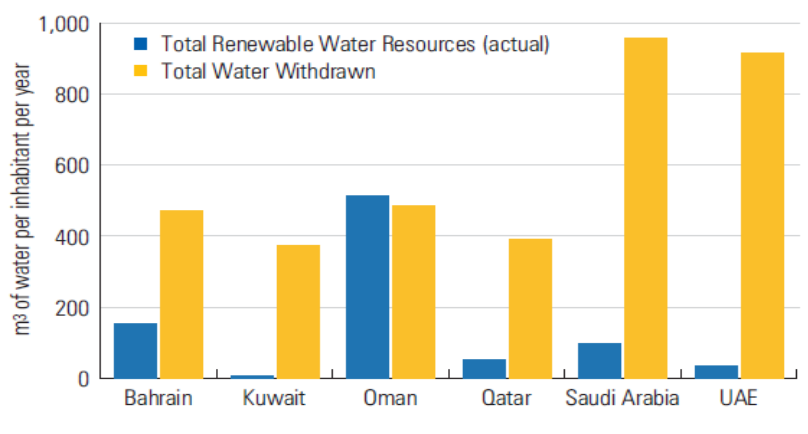

Figure 4: Renewable resources consumption.

it is sold for around USD 0.04. With the exception of the UAE, where Sharjah's Electricity and Water Authority sharply increased electricity prices in 2009 and other emirates are expected to follow, countries have been reluctant to reform tariffs. On average, demand for energy has increased in the GCC by 6 per cent annually. 223 In 2007, Bahrain, Kuwait, Qatar and the UAE were the first, third, fourth and fifthhighest $\mathrm{CO}_{2}$ per capita producers in the world. 224 as a whole, the GCC produces roughly half the carbon dioxide emissions produced in the Arab world. The GCC governments are developing new energy portfolios with a focus on nuclear and renewable energy. The UAE is the most active in planning its post-oil energy future and is the first Arab nation to develop nuclear power on a commercial scale. It aims to providethe majority of its electricity needs in 2020 from nuclear sources. A better understanding of the interrelationships of population, consumption, and environmental change is key to analyzing ecological footprint accounts. The insights gained from this analysis bring awareness of the implications of ecological limits on economic security and prosperity. The challenge becomes one of changing consumption patterns, development models, and economic policies, so that equilibrium can be reached with the Earth's ecosystems. By making these linkages explicit throughfurther analysis, decision makers will be better prepared to weigh available sustainability options

\section{Conclusion}

The Gulf Cooperation Council (GCC) countries have a population of over 40 million, With 80 per cent of the population living in urban areas, it is one of the most urbanized regions in the world. Nearly 40 per cent of the region's population is foreign born, most of whom are migrant labourers from Asia. Total population growth in the GCC countries is increasing.

The discovery of oil in the 1960s has resulted ininflux of migration tothe GCC States as a result of the prospers economic conditions. These countrieshave become over reliant on a large foreign workforce, to the extent that in many countries, foreign workers form the majority of their inhabitants. The fact that led to serious social economic and cultural challenges. Consequently, nationalization of human resources, has become the desired and stated policy ofthese countries. Education, training, the transfer of knowledge from expatriate to citizen, better approaches to encouraging citizens into the private sector, and the greater inclusion of women, are all significant challenges to be addressed to achieve that policy.

Revenues from oil have allowed GCC governments to subsidize the cost of water, electricity, oil, gas and food for decades, resulting in some of the highest per capita rates of water and energy consumption and waste generation in the world. Electricity costs on average USD 0.12 
Citation: Ramadan E (2015) Sustainable Urbanization in the Arabian Gulf Region: Problems and Challenges. Arts Social Sci J 6: 109. doi:10.4172/21516200.1000109

per kWh to produce in the Gulf, but is sold for USD 0.04 per kWh. With oil production peaking and predicted to become depleted in ten to 40 years, depending on the country, GCC governments are now investing heavily in alternative solutions, such as renewable and nuclear energy, wastewater reclamation, and waste recycling. As these areas that these governments can make improvement Given the political difficulty of implementing tariff and management policy reforms, the focus has been on technological and efficiency improvements. To improve water consumption habits through education and awareness. With its arid climate and rapidly-growing population, the Gulf is one of the world's most water-scarce regions. Despite the high cost of desalinization, water tariffs in the GCC are among the lowest in the world, and it was free for many years in Doha. As governments reevaluate water resource management, they are focusing on three main strategies: increasing the capacity of desalination plants; reforming tariffs and educating consumers and reducing domestic agriculture and promoting wastewater reuse.

\section{References}

1. Shammaa DE (2009) Capital will invest $\$ 68 b$ in transport. Gulf News, Department of Transport, Abu Dhabi.

2. Manni AA (2007) Urban growth and land use detection using remote sensing and geographical information system techniques in Doha City. Arab Gulf Journal of Scientific Research, State of Qatar 25(4): 190-198.

3. Daly HE (1996) Beyond Growth: The Economics of Sustainable Development Beacon Press, Boston 22(4): 783-789.
4. Sherbinin AD, Carr D, Cassels S, Jiang L (2007) Population and Environment Annual Review of Environment and Resources 32: 345-373.

5. Arifi E, Salih A (1986) The nature of urbanization in the gulf countries Department of Geography, University of Qatar, Qatar.

6. Habr E, Habib N (2007) Clean Drinking Water and Sanitation: The Experience I the Arab Region. UN Chronicle.

7. ESCWA (2005) Urbanization and the Changing Character of the Arab City.

8. ESCWA (2006) Activities of the Economic and Social Commission for Western Asia.

9. ESCWA (2005) The Millennium Development Goals in the Arab Region 2005 United Nations, New York.

10. Jeddah Municipality (2009) Jeddah Strategic Plan. Urban Land Use Patterns: 41.

11. Kharoufi M (2009) Urbanization and Urban Research in the Arab World Management of Social Transformations, UNESCO 1996, Ministry of National Economy, Statistical Yearbook, Paris.

12. (2010) Qatar Statistics Authority 2010 census. Source Data Qatar Information Exchange.

13. (2012) State of the Cities Background Report: Saudi Arabia. UN-Habitat, Nairobi.

14. (2008) The World Population Prospects: The 2008 Revision. UN Department of Economic and Social Affair, UN-DESA, New York.

15. The World Urbanization Prospects: The 2009 Revision. UN-Department of Economic and Social Affairs, UN-DESA, New York.

16. (2011) State of the Cities Background Report: Saudi Arabia. UN-Habitat, Nairobi. 